Note

\title{
CTAB METHODS FOR DNA EXTRACTION OF SWEETPOTATO FOR MICROSATELLITE ANALYSIS
}

\author{
Aline Borges ${ }^{1}$; Mariana Silva Rosa ${ }^{2}$; Gustavo Henrique Recchia ${ }^{1}$; Jurema Rosa de Queiroz- \\ Silva $^{3}$; Eduardo de Andrade Bressan ${ }^{1}$; Elizabeth Ann Veasey ${ }^{4 *}$ \\ ${ }^{1}$ USP/CENA - Programa de Pós-Graduação Biologia na Agricultura e no Ambiente. \\ ${ }^{2}$ UNESP/FCAV - Programa de Pós-Graduação em Produção e Tecnologia de Sementes. \\ ${ }^{2}$ UFRB - Programa de Pós-Graduação em Ciências Agrárias \\ ${ }^{4}$ USP/ESALQ - Depto. de Genética, C.P. 83 - 13400-970 - Piracicaba, SP - Brasil. \\ *Corresponding author <eaveasey@esalq.usp.br>
}

\begin{abstract}
Microsatellite markers have proved to be useful in genetic diversity assessments of sweetpotato (Ipomoea batatas) but practical DNA extraction methods to ensure good quality and quantity DNA for these studies are yet to be established. This study compares the efficiency of three modified methodologies for DNA extraction of six sweetpotato landraces using the CTAB extraction buffer in regard to quantity and purity of DNA quantification and microsatellite band patterns. All methodologies yielded satisfactory results, but the method based in leaf tissue macerated in liquid nitrogen was deemed more adequate because of its simplicity and lower cost. However, the method based in dry leaf tissue was considered more advantageous, first because elicits practicability in the plant acquisition and drying process, especially when the collection is performed in situ, and also because its simplicity makes possible the cold storage of the dry, ground samples for future DNA extractions.
\end{abstract}

Key words: Ipomoea batatas, SSR, DNA isolation, landraces, protocol

\section{MÉTODOS CTAB DE EXTRAÇÃO DE DNA PARA A ANÁLISE DE MICROSSATÉLITES EM BATATA-DOCE}

\begin{abstract}
RESUMO: Os marcadores microssatélites são úteis para a análise da diversidade genética de variedades tradicionais de batata-doce (Ipomoea batatas). Para estes estudos, métodos práticos de extração de DNA precisam ser estabelecidos para assegurar uma boa qualidade e quantidade de DNA extraído. Assim, foi comparada a eficiência de três metodologias para extração de DNA usando o tampão de extração $\mathrm{CTAB}$, todas com modificações. Para verificar a quantidade e pureza na quantificação de DNA, bem como o padrão de bandas de microssatélites para as três metodologias utilizaram-se seis etnovariedades de batata-doce. Os testes mostraram que as três metodologias apresentaram resultados satisfatórios. Uma das metodologias baseada em tecido foliar macerado em nitrogênio líquido mostrouse a mais adequada devido à simplicidade e menor custo. Entretanto, o método baseado em tecido foliar seco foi o mais vantajoso devido à praticidade na aquisição da planta e no processo de secagem, principalmente quando a coleção encontra-se em condições in situ, e pela possibilidade do armazenamento refrigerado das amostras secas e maceradas para futuras extrações de DNA.

Palavras-chaves: Ipomoea batatas, SSR, isolamento de DNA, etnovariedades, protocolo
\end{abstract}

\section{INTRODUCTION}

Sweetpotato [Ipomoea batatas (L.) Lam.] belongs to the Convolvulaceae family. The Ipomoea genus encompass 600-700 species, as many as 500 concentrated in the Americas, mostly native with few introduced species. Part of the Brazilian territory is considered a sweetpotato center of diversity. Within the species there is a high variability, probably because of its high ploidy level, which needs to be preserved and studied to contribute with future plant breeding programs (Austin \& Huamán, 1996; Austin, 1988).

Several genetic studies have been conducted with molecular markers in sweetpotato, such as RAPD (random amplified polymorphic DNA) (Ukoskit \& Thompson, 1997; Thompson et al., 1997; Sagredo et al., 1998; Zhang et al., 1998; Gickuki et al., 2003), DAF (DNA amplification fingerprinting) (He et al., 1995), 
microsatellites or SSR (simple sequence repeats) (Jarret \& Bowen, 1994; Buteler et al., 1999; Hu et al., 2004), ISSR (inter-simple sequence repeats) (Hu et al., 2003), AFLP (amplified fragment length polymorphism) (Zhang et al., 2000; Fajardo et al., 2002; Zhang et al., 2004; Bruckner, 2004), and SAMPL (selective amplification of microsatellite polymorphic loci) (Tseng et al., 2002). Among the DNA extraction methodologies used by these authors, Doyle \& Doyle (1990), with or without modifications and Gawel \& Jarret (1991), both based on CTAB (cetyltrimethylammonium bromide) extraction buffer, or Wilson et al. (1992), based on the MATAB (mixed alkyltrimethylammonium bromide) extraction buffer, were the preferred ones. Kim \& Hamada (2005) presented a rapid and reliable DNA extraction method for sweet-potato also based on CTAB extraction buffer. Other studies used the DNAzol methodology (Chomczynski et al., 1997; Buteler et al., 1999). In general, all these studies used the maceration of young leaves recently collected or freeze-dried with liquid nitrogen.

In this study, the widely used methodologies of Doyle \& Doyle (1987) and Doyle \& Doyle (1990), based on CTAB extraction buffer and the maceration of recently collected leaves with liquid nitrogen, were compared with the methodology used for cassava (Manihot esculenta Crantz) (Elias et al., 2004), with adaptations, based on $3 \% \mathrm{CTAB}$, using young leaves dried in an oven at $45^{\circ} \mathrm{C}$ for $72 \mathrm{~h}$. The use of dried leaves for DNA isolation, without using liquid nitrogen, has not yet been described for sweetpotato. This methodology was reported in the genetic diversity analysis of South American cassava landraces with SSR (Elias et al., 2004). Other studies with cassava used silica gel-dried leaves for DNA extraction ground in liquid nitrogen before adding the extraction buffer (Colombo, 2000a; Colombo, 2000b). However, the use of the dry leaves for DNA extraction in sweetpotato is original.

This study compares the three methodologies of Doyle \& Doyle (1987), Doyle \& Doyle (1990) and Elias et al. (2004), with modifications, to the original methods. The extracted DNA was then used in SSR analysis to compare band standards and to test the efficient of the methodologies for future studies.

\section{MATERIAL AND METHODS}

\section{Plant materials}

Sweetpotato landraces used in this study were sampled at Iguape $\left(24^{\circ} 42^{\prime} \mathrm{S}, 47^{\circ} 33^{\prime} \mathrm{W}\right)$ and Cananéia ( $25^{\circ} 00^{\prime}$ S, $\left.47^{\circ} 55^{\prime} \mathrm{W}\right)$, São Paulo State, Brazil (Table 1), from an ex situ germplasm collection of the Genetics Department of Escola Superior de Agricultura "Luiz de Queiroz", University of São Paulo, Brazil.

\section{DNA extraction}

DNA extraction methodologies of Doyle \& Doyle (1987), Doyle \& Doyle (1990) and Elias et al. (2004) based in Dellaporta et al. (1983), all with modifications from the original methods, were compared. Recently expanded young leaves of sweetpotato were collected early in the morning from a multiplication field, washed and dried with paper towels to eliminate excess dirt, and then submitted to the following DNA extraction methods:

\section{A) Modified Doyle \& Doyle (1987) methodology}

- 50-mg samples of young leaf tissues were ground to a fine powder in liquid nitrogen;

- powder was then placed in 1.5-mL microtubes containing $700 \mu \mathrm{L} 2 \%$ CTAB extraction buffer $[20 \mathrm{mM}$ EDTA, $0.1 \mathrm{M}$ Tris-HCl pH 8.0, $1.4 \mathrm{M} \mathrm{NaCl}, 2 \%$ CTAB, plus $0.4 \% \quad \beta$-mercaptoethanol added just before use];

- the solution was incubated at $65^{\circ} \mathrm{C}$ for $45 \mathrm{~min}$, gently mixing by inversion every $15 \mathrm{~min} ; 500 \mu \mathrm{L}$ of chloroform-isoamylalcohol (24:1) was added to the tubes and gently mixed for $1 \mathrm{~min}$;

- samples were centrifuged for $10 \mathrm{~min}$. at 12,000 rpm; $600 \mu \mathrm{L}$ of the supernatant was then transferred to a fresh tube following the addition of $500 \mu \mathrm{L}$ chloroform-isoamylalcohol (24:1); this procedure was repeated twice;

- $500 \mu \mathrm{L}$ of the supernatant was then transferred to a fresh tube with $700 \mu \mathrm{L}$ of cold isopropanol $\left(-20^{\circ} \mathrm{C}\right)$; samples were gently mixed by inversion and centri-

Table 1 - List of the sweetpotato landraces assessed in this study and their origin.

\begin{tabular}{lcccccc}
\hline Landrace & Landrace code & Municipality & Community & Local names & Latitude & Longitude \\
\hline 1 & DGB 5.0 & Iguape & Pontal de Icapara & Native/Sambaqui & $24^{\circ} 39^{\prime} \mathrm{S}$ & $47^{\circ} 26^{\prime} \mathrm{W}$ \\
2 & DGB 10.0 & Iguape & Praia do Leste & Purple potato & $24^{\circ} 40^{\prime} \mathrm{S}$ & $47^{\circ} 25^{\prime} \mathrm{W}$ \\
3 & DGB 23.0 & Iguape & Cavalcanti & White potato & $24^{\circ} 42^{\prime} \mathrm{S}$ & $47^{\circ} 41^{\prime} \mathrm{W}$ \\
4 & DGB 32.0 & Cananéia & Agrossolar & Rio Grande potato & $24^{\circ} 58^{\prime} \mathrm{S}$ & $47^{\circ} 54^{\prime} \mathrm{W}$ \\
5 & DGB 40.0 & Cananéia & S.P. Bagre & White potato & $24^{\circ} 57^{\prime} \mathrm{S}$ & $47^{\circ} 53^{\prime} \mathrm{W}$ \\
6 & DGB 42.0 & Cananéia & Aroeira & White potato & $24^{\circ} 52^{\prime} \mathrm{S}$ & $47^{\circ} 52^{\prime} \mathrm{W}$
\end{tabular}


fuged at $12,000 \mathrm{rpm}$ for $10 \mathrm{~min}$, and so it was possible to visualize the DNA adhered to the bottom of the tube;

- the liquid solution was then released and the DNA pellet washed with $700 \mu \mathrm{L}$ of $70 \%$ ethanol to eliminate salt residues adhered to the DNA, and set to dry for approximately $12 \mathrm{~h}$, or until the next day, with the tubes inverted over a filter paper, at room temperature;

- the pellet was then ressuspended in $100 \mu \mathrm{L}$ TE buffer (10 mM Tris-HCl pH 8.0, 1 mM EDTA pH 8.0) plus $5 \mu \mathrm{L}$ ribonuclease (RNAse $10 \mathrm{mg} \mathrm{mL}^{-1}$ ) in each tube; this solution was incubated at $37^{\circ} \mathrm{C}$ for $1 \mathrm{~h}$, and after stored at $-20^{\circ} \mathrm{C}$.

\section{B) Modified Doyle \& Doyle (1990) methodology}

- young leaves were ground to a fine powder in liquid nitrogen;

- the powder $(50 \mathrm{mg})$ was placed in $1.5-\mathrm{mL}$ microtubes containing $400 \mu \mathrm{L}$ of the $2 \%$ CTAB extraction buffer with modifications [20mM EDTA, $0.1 \mathrm{M}$ Tris-HCl pH 8.0, $1.4 \mathrm{M} \mathrm{NaCl}, 2 \%$ CTAB, plus $1 \% \beta$ mercaptoethanol added just before use]; microtubes were then vortexed for $10 \mathrm{~s}$ and incubated at $60^{\circ} \mathrm{C}$ for 30 min;

- next, $60 \mu \mathrm{L}$ of chloroform-isoamylalcohol (24:1) was added to the solution, which was vortexed for $10 \mathrm{~s}$ and centrifuged at 10,000 rpm for $3 \mathrm{~min}$; the supernatant was transferred to a fresh tube and this stage was repeated once;

- cold isopropanol $\left(-20^{\circ} \mathrm{C}\right)$ was added to the supernatant ( 0.7 of the total volume of supernatant collected); samples were gently mixed by inversion and centrifuged at 10,000 rpm for $3 \mathrm{~min}$; the DNA pellet adhered to the tube was then visualized;

- the liquid phase was then released and DNA washed twice with $500 \mu \mathrm{L} \mathrm{70 \%} \mathrm{ethanol;} \mathrm{the} \mathrm{pellet} \mathrm{was} \mathrm{set} \mathrm{to}$ dry for approximately $12 \mathrm{~h}$ with the tubes inverted upon filter paper at room temperature;

- the pellet was ressuspended in $100 \mu \mathrm{L}$ TE buffer solution plus $5 \mu \mathrm{L}$ RNAse $\left(10 \mathrm{mg} \mathrm{mL}^{-1}\right)$; the solution was then incubated at $37^{\circ} \mathrm{C}$ for $1 \mathrm{~h}$, and after stored at $20^{\circ} \mathrm{C}$.

C) Modified Elias et al. (2004), based on CTAB extraction buffer, Dellaporta et al. (1983) methodology

- recently expanded young leaves were dehydrated in the oven at $45^{\circ} \mathrm{C}$ for $72 \mathrm{~h}$, and then ground to fine powder in porcelain crucibles; the powder was stored in $1.5 \mathrm{~mL}$ microtubes at $-20^{\circ} \mathrm{C}$ until use;
- a $50 \mathrm{mg}$ sample was then transferred to a fresh, 1.5$\mathrm{mL}$ microtube containing $800 \mu \mathrm{L}$ of $3 \%$ CTAB extraction buffer [30mM EDTA, 0.1 M Tris-HCl pH 8.0, 1.2 $\mathrm{M} \mathrm{NaCl}, 3 \% \mathrm{CTAB}$, plus 3\% $\beta$-mercaptoethanol added just before use].

- tubes were then incubated at $65^{\circ} \mathrm{C}$ for $1 \mathrm{~h}$, gently mixed every $15 \mathrm{~min}$ for adequate homogenization;

- $500 \mu \mathrm{L}$ of chloroform-isoamylalcohol (24:1) was then added, mixed gently for $1 \mathrm{~min}$, and centrifuged at 8,000 rpm for $10 \mathrm{~min}$;

- after centrifugation, $500 \mu \mathrm{L}$ of the supernatant was transferred to a fresh tube with an equal volume of chloroform-isoamylalcohol (24:1) plus $200 \mu \mathrm{L} \mathrm{CTAB}$ $3 \%$ (without $\beta$-mercaptoethanol); this solution was mixed gently and centrifuged again at $8,000 \mathrm{rpm}$ for 10 min and $500-\mu \mathrm{L}$ sample of the supernatant was transferred to a fresh tube with $350 \mu \mathrm{L}$ cold isopropanol at $-20^{\circ} \mathrm{C}$, and gently mixed by inversion;

- the solution was centrifuged at 8,000 rpm for $10 \mathrm{~min}$, and the resulting pellet was set to dry for approximately $12 \mathrm{~h}$ with the tubes inverted over a filter paper at room temperature;

- the pellet was ressuspended in TE buffer solution, adding $200 \mu \mathrm{L}$ TE and $4 \mu \mathrm{L}$ de RNAse $\left(10 \mathrm{mg} \mathrm{mL}^{-1}\right)$; the tubes were incubated at $37^{\circ} \mathrm{C}$ for $30 \mathrm{~min}$, and then stored at $-20^{\circ} \mathrm{C}$.

\section{DNA quantification}

DNA was quantified in $4 \%$ polyacrylamide gels. Electrophoresis was conducted in a $1 \mathrm{X}$ TBE buffer [100 mL 10X TBE (0.89M Tris base, 0.89M Boric acid, $20 \mathrm{mM}$ EDTA pH 8.0) and $900 \mathrm{~mL}$ distilled water] at $60 \mathrm{~V}$ for 30 min and then at $120 \mathrm{~V}$ for $1.5 \mathrm{~h}$. The gel was then stained in silver nitrate (Bassam et al., 1991), using $125 \mathrm{~mL}$ fixation buffer (10\% absolute ethanol, 5\% absolute acetic acid, $895 \mathrm{~mL}$ distilled water) and $0.2 \%$ silver nitrate for $5 \mathrm{~min}$. The gel then was washed twice with $150 \mathrm{~mL}$ distilled water, and stained with $125 \mathrm{~mL}$ revelation buffer (30\% sodium hydroxide in $1000 \mathrm{~mL}$ distilled water), adding $0.4 \%$ phormaldeid.

\section{PCR amplification and electrophoresis}

Eight primers (Table 2) were used for each DNA extraction method and assessed landraces. PCR reactions were conducted at a final volume of $10.2 \mu \mathrm{L}$, containing $0.2 \mu \mathrm{L} \mathrm{Taq}$ polymerase $\left(5\right.$ units $\left.\mu \mathrm{L}^{-1}\right), 1.0$ $\mu \mathrm{L}$ 10X Amplification Buffer $\left(\mathrm{Mg}^{+}\right.$Free $), 1.0 \mu \mathrm{L} \mathrm{MgCl}$ $(50 \mathrm{mM}), 0.5 \mu \mathrm{L}$ Forward Primer $\left(5\right.$ pmoles $\left.\mu \mathrm{L}^{-1}\right), 0.5$ $\mu \mathrm{L}$ Reverse Primer $\left(5\right.$ pmoles $\left.\mu \mathrm{L}^{-1}\right), 1.0 \mu \mathrm{L}$ dNTP's (2.5 mM each), $3 \mu \mathrm{L}$ de Milli-Q HO and $3 \mu \mathrm{L}$ DNA $\left(5 \mathrm{ng} \mu \mathrm{L}^{-1}\right)$. The PCR reaction conditions, conducted 
Table 2 - List of the eight primers ${ }^{1}$ used for the DNA amplification of sweetpotato varieties, showing their expected fragment sizes and annealing temperatures used in this study.

\begin{tabular}{|c|c|c|c|}
\hline Locus & Primer pairs $5^{\prime} \rightarrow 3^{\prime}$ & Expected size (bp) & Annealing temperature \\
\hline $\mathrm{Ib}-316$ & $\begin{array}{l}\text { F: CAAACGCACAACGCTGTC } \\
\text { R: CGCGTCCCGCTTATTTAAC }\end{array}$ & $140-155$ & $60^{\circ} \mathrm{C}$ \\
\hline Ib - 318 & $\begin{array}{c}\text { F: AGAACGCATGGGCATTGA } \\
\text { R: CCCACCGTGTAAGGAAATCA }\end{array}$ & $125-135$ & $53^{\circ} \mathrm{C}$ \\
\hline $\mathrm{Ib}-255 \mathrm{~F} 1$ & $\begin{array}{l}\text { F: CGTCCATGCTAAAGGTGTCAA } \\
\text { R: ATAGGGGATTGTGCGTAATTTG }\end{array}$ & $210-245$ & $53^{\circ} \mathrm{C}$ \\
\hline $\mathrm{Ib}-286$ & $\begin{array}{c}\text { F: AGCCACTCCAACAGCACATA } \\
\text { R: GGTTTCCCAATCAGCAATTC }\end{array}$ & $90-122$ & $51^{\circ} \mathrm{C}$ \\
\hline $\mathrm{Ib}-255$ & $\begin{array}{l}\text { F: TGGGCATTCTCATATTTTGCT } \\
\text { R: GCCACTCCAACAGCACATAA }\end{array}$ & $165-170$ & $62^{\circ} \mathrm{C}$ \\
\hline Ib-242 & $\begin{array}{c}\text { F: GCGGAACGGACGAGAAAA } \\
\text { R: ATGGCAGAGTGAAAATGGAACA }\end{array}$ & $105-142$ & $52^{\circ} \mathrm{C}$ \\
\hline Ib-248 & $\begin{array}{l}\text { F: GAGAGGCCATTGAAGAGGAA } \\
\text { R: AAGGACCACCGTAAATCCAA }\end{array}$ & $155-170$ & $62^{\circ} \mathrm{C}$ \\
\hline Ib - 297 & $\begin{array}{l}\text { F: CAАTTTCACACACAAACACG } \\
\text { R: CССТTCTTCCАССАСТTTCA }\end{array}$ & $130-200$ & $51^{\circ} \mathrm{C}$ \\
\hline
\end{tabular}

Table 3 - DNA concentration of the sweetpotato $50 \mathrm{mg}$ tissue sampled for three methodologies tested: (A) Elias et al. (2004), (B) Doyle \& Doyle (1990), and (C) Doyle \& Doyle (1987).

\begin{tabular}{lcccc}
\hline \multirow{2}{*}{ Landrace } & \multirow{2}{*}{ Landrace code } & \multicolumn{3}{c}{ DNA concentration } \\
\cline { 3 - 5 } & & A & B & C \\
\hline & & ---1 & ng $\mu \mathrm{L}^{-1}$ & ------ \\
2 & DGB 5.0 & 30 & 80 & 50 \\
3 & DGB 10.0 & 10 & 60 & 20 \\
4 & DGB 23.0 & 40 & 30 & 30 \\
5 & DGB 32.0 & 30 & 30 & 30 \\
6 & DGB 40.0 & 40 & 40 & 30 \\
& DGB 42.0 & 30 & 20 & 30
\end{tabular}

at a MyCycler BioRad thermocycler, were the following: $3 \mathrm{~min}$ at $95^{\circ} \mathrm{C} ; 5$ cycles of $45 \mathrm{~s}$ at $94^{\circ} \mathrm{C}, 15 \mathrm{~s}$ for the primer annealing temperature (Table 2 ), $45 \mathrm{~s}$ at $72^{\circ} \mathrm{C}$; and 20 cycles of $1 \mathrm{~min}$ at $90^{\circ} \mathrm{C}, 1 \mathrm{~min}$ for the annealing temperature, $1 \mathrm{~min}$ at $72^{\circ} \mathrm{C}$; and $7 \mathrm{~min}$ at $72^{\circ} \mathrm{C}$ for the final extension (Buteler et al., 1999).

The products of amplification were separated in $6 \%$ polyacrilamyde gels, at $60 \mathrm{~V}$ for $30 \mathrm{~min}$ and $120 \mathrm{~V}$ for $3 \mathrm{~h}$. Ladders of 10bp (Invitrogen) and 100bp (AMRESCO) were used as molecular weight patterns. The gels were stained in silver nitrate, as described for the DNA quantification and photodocumented with a digital camera.

\section{RESULTS AND DISCUSSION}

The three methodologies yielded satisfactory results for DNA extraction, quantification and microsatellites band resolution for all sweetpotato landraces (Figures 1 and 2). Although the DNA concentration was higher for both Doyle \& Doyle methods in landraces 1 and 2 when compared to the Elias et al. (2004) method, which is composed of an aggressive process for DNA extraction of dried material, for the other landraces the DNA concentration was equivalent for the three methodologies (Table 3). However, the Elias et al. (2004) methodology showed better quality DNA because of the lower incidence of impurities compared to the other methods. This could be related with the modifications in the methodology based on dry leaves.

Being an hexaploid species (Ozias-Akins \& Jarret, 1994), sweetpotato shows complex microsatellite band patterns (Figure 2). Considering the band patterns shown by the three methodologies, although a few landraces did not present good band resolution, in general, the three methodologies showed the same band patterns. For example, two bands were considered for landraces 5 and 6 for primers Ib-297 and Ib-286, respectively, while three bands were considered for landrace 2 for primer Ib-242.

Few modifications were made from the original CTAB method used by Elias et al. (2004), based on Dellaporta et al. (1983), such as temperature and drying time in the oven, performed in this study at $45^{\circ} \mathrm{C}$ for $72 \mathrm{~h}$. The lower temperature was important to obtain higher DNA quantity in each sample. The $1 \% \beta$ mercaptoethanol concentration was increased to $3 \%$. Although this increase contributed to a lower DNA quantity, it was important to obtain a more purified DNA. This concentration can be increased up to 5\% (Pereira et al., 2007), depending on the quality of the material. Another modification was the addition of $200 \mu \mathrm{L} \mathrm{CTAB}$ $3 \%$ (without $\beta$-mercaptoethanol) to the DNA purification stage with chloroform-isoamylalcohol (24:1), which was important to increase DNA purification. 


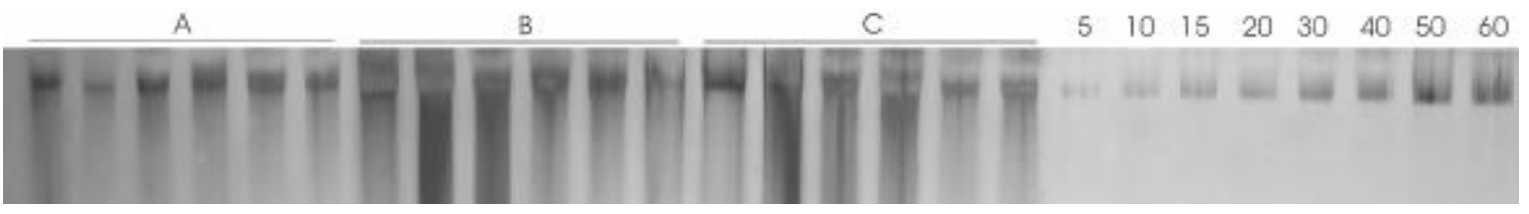

Figure 1 - Quantification polyacrilamyde gel showing the three methodologies: (A) Elias et al. (2004), (B) Doyle \& Doyle (1990) and (C) Doyle \& Doyle (1987), all with modifications, plus eight DNA markers, varying from 5 to $60 \mathrm{ng} \mu \mathrm{L}^{-1}$ Lambda DNA.
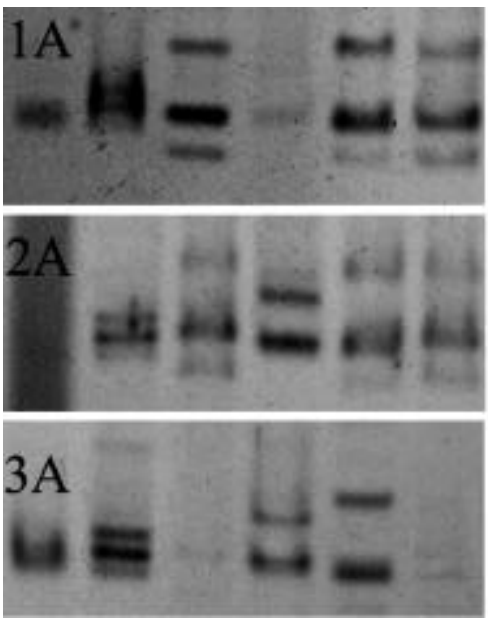
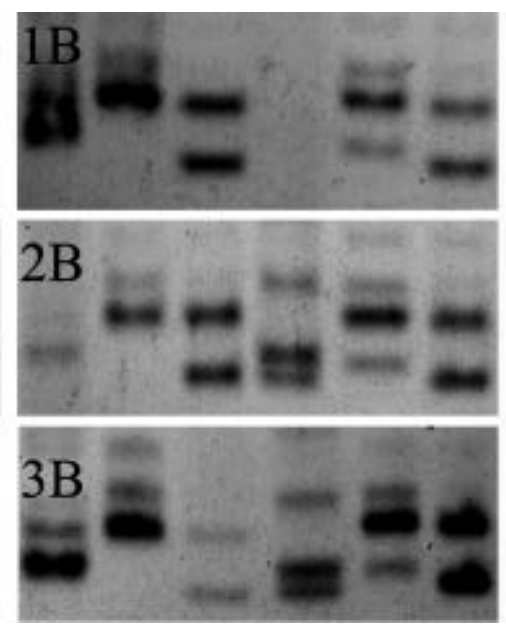
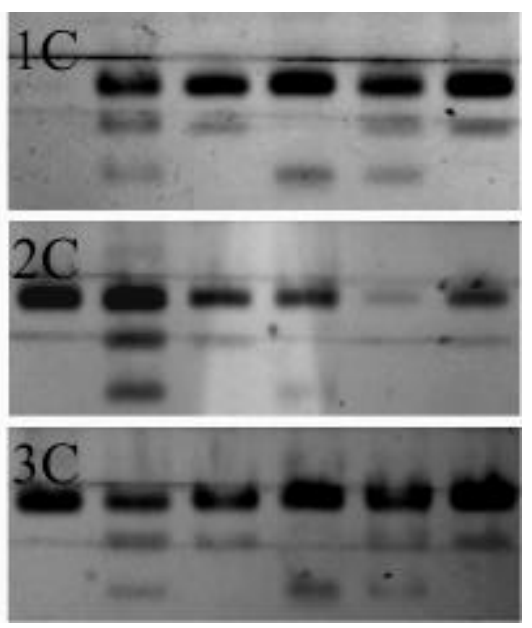

Figure 2 - Microsatellite band patterns obtained for three primers (A: Ib-297; B: Ib-286; C: Ib-242) and six sweetpotato landraces (1, 2, 3, 4, 5, 6, from left to right), for the three DNA extraction methodologies: (1) Elias et al. (2004), (2) Doyle \& Doyle (1990) and (3) Doyle \& Doyle (1987).

Doyle \& Doyle (1990) method was considered more practicable because required fewer centrifugations with less reagents. Also, a modification to one of the stages of Doyle \& Doyle (1990) included the substitution of a refrigerated microcentrifuge for a non-refrigerated microcentrifuge. However, the Elias et al. (2004) methodology, used for cassava with modifications, presents an advantage over the other two methodologies in using dried leaf material compared to grinding of recently collected or freeze-dried leaves in liquid nitrogen. During plant collection, one of the difficulties is the storing of the material before analysis, especially when laboratory facilities are distant. Thus, this method is useful, for example, when in situ and on farm sweetpotato collections are made. When using freeze-dried leaves, they usually need to be immediately immersed into liquid nitrogen and transported to a $-20^{\circ} \mathrm{C}$ or $-80^{\circ} \mathrm{C}$ freezer until its use. With the Elias et al. (2004) modified methodology, even sun dried leaves may be used, or young leaves mounted within sheets of folded newspaper which are then left to dry in plant presses at room temperature (Pereira et al., 2007) or in the sun. Moreover, the young leaves can be packed within two sheets of filter paper together with silica gel to be left at the laboratory for dehydration. The fine powder obtained after grinding can be easily stored in $1.5 \mathrm{~mL}$ microtubes at $-20^{\circ} \mathrm{C}$ for further analysis.

Most genetic studies using molecular markers in sweetpotato have used methods based on the $2 \%$ CTAB buffer extraction, such as those of Doyle \& Doyle (1990), with or without modification (Tseng et al., 2002; Zhang et al., 1998, 2000, 2004; Hu et al., 2003, 2004), or the Gawel \& Jarret (1991) method (Ukoskit \& Thompson, 1997), or the Rogers \& Bendich (1988) modified method (Sagredo et al., 1998). He et al. (1995) and Prakash et al. (1996) used methods based on the MATAB 2\% extraction buffer, such as Wilson et al. (1992). Other studies used the DNAzol reagent method (Chomczynski et al., 1997; Buteler et al., 1999), or the 'Dneasy plant minikit' (QIAGEN) (Gichuki et al., 2003), or also the Promega Wizard $^{\circledR}$ Magnetic 96 DNA Plant System extraction method (Madison, WI) (Bruckner, 2004). All methodologies cited above used recently collected young leaves ground in liquid nitrogen (He et al., 1995; Prakash et al., 1996; Thompson et al., 1997; Zhang et al., 1998; Tseng et al., 2002; Hu et al., 2003, 2004) or freezedried leaves stored at $-20^{\circ} \mathrm{C}$ or $-80^{\circ} \mathrm{C}$ (Fajardo et al., 2002; Gichuki et al., 2003; Bruckner, 2004). Until now, apparently no studies with sweetpotato molecular markers have used young leaves dehydrated in the oven for DNA extraction. 
Summing up, all three methodologies tested in this study were shown to be adequate for microsatellites studies in sweetpotato. However, the cassava Elias et al. (2004) modified methodology is recommended for sweetpotato based on 3\% CTAB and dehydrated young leaves, due to lesser costs and the practicability of the method, especially considering an in situ plant collection.

\section{ACKNOWLEDGEMENTS}

To the program Biota/FAPESP and CNPq for providing financial support and scholarships.

\section{REFERENCES}

AUSTIN, D.F. The taxonomy, evolution and genetic diversity of sweetpotatoes and related wild species. In: SWEET POTATO PLANING CONFERENCE, 1., Lima, 1987. Report. Lima: CIP, 1988. 369p.

AUSTIN, D.F.; HUÁMAN, Z. A synopsis of Ipomoea (Convolvulaceae) in the Americas. Taxon, v.45, p.3-38, 1996.

BASSAM, B.J.; CAETANO-ANOLLES, G.; GRESSHOFF, P.M. Fast and sensitive silver staining of DNA in polyacrylamide gels. Analytical Biochemistry, v.196, p.80-83, 1991.

BRUCKNER, A.W. AFLP-based genetic diversity assessment of global sweetpotato (Ipomoea batatas (L.) Lam.) germplasm resources: progress toward the development of a sweetpotato core collection. Raleigh: North Caroline State University, 2004. 211p. Dissertation (MSc).

BUTELER, M.I.; JARRET, R.L.; LA BONTE, D.R. Sequence characterization of microsatellites in diploid and polyploid Ipomoea. Theoretical and Applied Genetics, v.99, p.123-132, 1999.

CHOMCZYNSKI, P.; MACKEY, K.; DREWS, R.; WILFINGER, W. DNAzol: a reagent for the rapid isolation of genomic DNA. Biotechniques, v.22, p.550-553, 1997.

COLOMBO, C.; SECOND, G.; ANDRÉ, C. Diversity within American cassava germ plasm based on RAPD markers. Genetics and Molecular Biology, v.23, p.189-199, 2000a.

COLOMBO, C.; SECOND, G., CHARRIER, A. Genetic relatedness between cassava (Manihot esculenta Crantz) and M. flabellifolia and $M$. peruviana based on both RAPD and AFLP markers. Genetics and Molecular Biology, v.23, p.417-423, 2000b.

DELLAPORTA, S.L.; WOOD, J.; HICKS, J.B. A plant DNA minipreparation: version II. Plant Molecular Biology Reporter, v.1, p.19-21, 1983.

DOYLE, J.J.; DOYLE, J.L. A rapid DNA isolation procedure for small quantities of fresh leaf tissue. Phytochemical Bulletin, v.19, p.11-15, 1987.

DOYLE, J.J.; DOYLE J.L. Isolation of plant DNA from fresh tissue. Focus, v.12, p.13-15, 1990.

ELIAS, M.; MÜHLEN, G.S.; McKEY, D.; ROA, A.C.; TOHME, J. Genetic diversity of traditional South American landraces of cassava (Manihot esculenta Crantz): an analysis using microsatellites. Economic Botany, v.58, p.242-256, 2004.

FAJARDO, D.S.; LA BONTE, D.R.; JARRET, R.L. Identifying and selecting for genetic diversity in Papua New Guinea sweepotato Ipomoea batatas (L.) Lam. germplasm collected as botanical seed. Genetic Resources Crop Evolution, v.49, p.463-470, 2002.

GAWEL, N.L.; JARRET, R.L. A modified CTAB DNA extraction procedure of Musa and Ipomoea. Plant Molecular Biology Reporter, v.9, p.262-266, 1991.

GICHUKI, S.T.; BERENYI, M.; ZHANG, D.; HERMANN, M.; SCHMIDT, J.; GLÖSSL, J.; BURG, K. Genetic diversity in sweetpotato [Ipomoea batatas (L.) Lam.] in relationship to geographic sources as assessed with RAPD markers. Genetic Resources Crop Evolution, v.50, p.429-437, 2003.
HE, G.; PRAKASH, C.S.; JARRET, R.L. Analysis of genetic diversity in a sweetpotato (Ipomoea batatas) germplasm collection using DNA amplification fingerprinting. Genome, v.38, p.938-945, 1995.

HU, J.; NAKATANI, M.; LALUSIN, A.G.; KURANOUCHI, T.; FUJIMURA, T. Genetic analysis of sweetpotato and wild relatives using Inter-Simple Sequence Repeats (ISSRs). Breeding Science, v.53, p.297-304, 2003.

HU, J.; NAKATANI, M.; MIZUNO, K; FUJIMURA, T. Development and characterization of microsatellite markers in sweetpotato. Breeding Science, v.54, p.177-188, 2004.

JARRET, R.L.; BOWEN, N. Simple Sequence Repeats (SSRs) for sweetpotato germplasm characterization. Plant Genetic Resources Newsletter, v.100, p.9-11, 1994.

KIM, S.H.; HAMADA, T. Rapid and reliable method of extracting DNA and RNA from sweetpotato, Ipomoea batatas (L). Lam. Biotechnology Letters, v.27, p.1841-1845, 2005.

OZIAS-AKINS, P.; JARRET, R.L. Nuclear DNA content and ploidy levels in the genus Ipomoea. Journal of the American Society for Horticultural Sciences, v.119, p.110-115, 1994.

PEREIRA, K.J.C.; BORGES, A.; VEASEY, E.A. Diversidade genética de mandioca em roças de agricultura tradicional na Reserva Amanã (RDSA), Amazônia. Revista da Associação Brasileira de Horticultura, v.25, p.86, suplemento, 2007.

PRAKASH, C.S.; HE, G.; JARRET, R.L. DNA marker-based study of genetic relatedness in United States sweetpotato cultivars. Journal of the American Society for Horticulture Science, v.121, p.1059-1062, 1996.

ROGERS, S.O.; BENDICH, A.J. Extraction of DNA from plant tissues. In: GELVIN, S.V.; SCHILPEROORT, R.A.; VERMA, D.P.S. (Ed.) Plant molecular biology manual. Dordrecht: Kluwer Academic, 1988. cap.6, p.1-10.

SAGREDO, B.; HINRICHSEN, P.; LÓPEZ, H.; CUBILLOS, A.; MUÑOZ, C. Genetic variation of sweet potatoes (Ipomoea batatas L.) cultivated in Chile determined by RAPDs. Euphytica, v.101, p.193-198, 1998.

THOMPSON, P.G.; HONG, L.L.; UKOSKIT, K.; ZHU, S. Genetic linkage of randomly amplified polymorphic DNA (RAPD) markers in sweetpotato. Journal of the American Society for Horticultural Science, v.122, p.79-82, 1997.

TSENG, Y.T.; LO, H.F.; HWANG, S.Y. Genotyping and assessment of genetic relationships in elite polycross breeding cultivars of sweet potato in Taiwan based on SAMPL polymorphisms. Botanical Bulletin of Academia Sinica, v.43, p.99-105, 2002.

UKOSKIT, K.; THOMPSON, P.G. Autopolyploidy versus allopolyploidy and low-density randomly amplified polymorphic DNA linkage maps of sweetpotato. Journal of the American Society for Horticultural Science, v.122, p.822-828, 1997.

WILSON, H.D.; DOEBLY, J.; DUVALL, M. Chloroplast DNA diversity among wild and cultivated members of Cucurbita (Cucurbitaceae). Theoretical and Applied Genetics, v.84, p. 859-865, 1992.

ZHANG, D.; GHISLAIN, M.; HUAMÁN, Z.; GOLMIRZAIE, A.; HIJMANS, R. RAPD variation in sweetpotato [Ipomoea batatas (L.) Lam.] cultivars from South America and Papua New Guinea. Genetic Resources Crop Evolution, v.45, p.271-277, 1998.

ZHANG, D.; CERVANTES, J.; HUAMÁN, Z.; CAREY, E.; GHISLAIN, M. Assessing genetic diversity of sweet potato (Ipomoea batatas (L.) Lam.) cultivars from tropical America using AFLP. Genetic Resources Crop Evolution, v.47, p.659-665, 2000.

ZHANG, D.; ROSSEL, G.; KRIEGNER, A.; HIJMANS, R. AFLP assessment of diversity in sweetpotato from Latin America and the Pacific region: its implications on the dispersal of the crop. Genetic Resources Crop Evolution, v.51, p.115-120, 2004.

Received October 19, 2007

Accepted December 12, 2008 